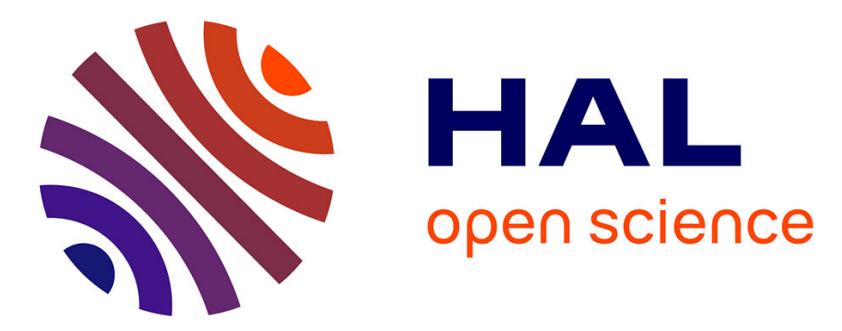

\title{
Mutation analysis of hBUB1, hBUBR1 and hBUB3 genes in glioblastomas
}

\author{
R M Reis, M Nakamura, J Masuoka, T Watanabe, Stefano Colella, Y \\ Yonekawa, P Kleihues, H Ohgaki
}

\section{- To cite this version:}

R M Reis, M Nakamura, J Masuoka, T Watanabe, Stefano Colella, et al.. Mutation analysis of hBUB1, hBUBR1 and hBUB3 genes in glioblastomas. Acta Neuropathologica Communications, 2001, 101 (4), pp.297-304. hal-02675782

\section{HAL Id: hal-02675782 \\ https://hal.inrae.fr/hal-02675782}

Submitted on 31 May 2020

HAL is a multi-disciplinary open access archive for the deposit and dissemination of scientific research documents, whether they are published or not. The documents may come from teaching and research institutions in France or abroad, or from public or private research centers.
L'archive ouverte pluridisciplinaire HAL, est destinée au dépôt et à la diffusion de documents scientifiques de niveau recherche, publiés ou non, émanant des établissements d'enseignement et de recherche français ou étrangers, des laboratoires publics ou privés. 


\section{Rui M. Reis $\cdot$ Mitsutoshi Nakamura $\cdot$ Jun Masuoka \\ Takao Watanabe $\cdot$ Stefano Colella \\ Yasuhiro Yonekawa Paul Kleihues $\cdot$ Hiroko Ohgaki \\ Mutation analysis of $h B U B 1, h B U B R 1$ and $h B U B 3$ genes in glioblastomas}

Received: 24 November 2000 / Accepted: 18 January 2001 / Published online: 29 March 2001

(C) Springer-Verlag 2001

\begin{abstract}
Glioblastomas, the most malignant human brain tumors, are characterized by marked aneuploidy, suggesting chromosomal instability which may be caused by a defective mitotic spindle checkpoint. We screened 22 glioblastomas for mutations in the mitotic spindle checkpoint genes $h B U B 1, h B U B R 1$ and $h B U B 3$. DNA sequencing revealed a silent mutation at codon 144 of $h B U B 1$ $(\mathrm{CAG} \rightarrow \mathrm{CAA}, \mathrm{Gln} \rightarrow \mathrm{Gln})$ in one glioblastoma, a silent mutation at codon 952 of $h B U B R 1$ (GAC $\rightarrow \mathrm{GAT}$, Asp $\rightarrow$ Asp) in another glioblastoma, and a silent mutation at codon 388 of the $h B U B R l$ gene $(\mathrm{GCG} \rightarrow \mathrm{GCA}, \mathrm{Ala} \rightarrow \mathrm{Ala})$ in 8 glioblastomas. We also observed a known polymorphism at $h B U B R 1$ codon 349 (CAA/CGA, Gln/Arg), with an allelic frequency of 0.75 for Gln and 0.25 for Arg, which is similar to that among healthy Caucasian individuals (0.73 vs 0.27$)$. The coding sequence of the $h B U B 3$ gene did not contain any mutation, but in 4 glioblastomas (18\%), a $\mathrm{C} \rightarrow \mathrm{T}$ point mutation was detected at position -6 (6 nucleotides upstream of the ATG initiator codon). Analysis of blood DNA of these patients showed identical sequence alterations, indicating that this is a polymorphism. Again, the frequency in glioblastomas was similar to that in healthy Caucasians $(15 \%)$. We further screened hBUB1 in 18 cases of giant cell glioblastoma, a variant characterized by a predominance of bizarre, multinucleated giant cells. There were no changes, except for a silent mutation at codon 144 in two cases. These results suggest that mutations in these mitotic spindle checkpoint genes do not play a significant role in the causation of chromosomal instability in glioblastomas.
\end{abstract}

R. M. Reis · M. Nakamura · J. Masuoka $\cdot$ T. Watanabe S. Colella $\cdot$ P. Kleihues $\cdot$ H. Ohgaki (®)

International Agency for Research on Cancer,

150 cours Albert Thomas, 69372 Lyon Cedex 08, France

e-mail: ohgaki@iarc.fr,

Tel.: +33-472-738534, Fax: +33-472-738564

Y. Yonekawa

The Department of Neurosurgery, University Hospital Zurich, 8091 Zurich, Switzerland
Keywords Mitotic checkpoint . hBUB1/hBUBR1/hBUB3 · Glioblastoma · Giant cell glioblastoma $\cdot$ Polymorphism

\section{Introduction}

Genetic instability is a critical phenomenon in the development of malignant human neoplasms and occurs in two different forms, microsatellite instability and chromosomal instability [22, 24, 27, 37]. In subsets of colorectal, gastric and endometrial cancers, defective mismatch repair results in increased mutation rates at the nucleotide level and, consequently, widespread microsatellite instability $[22,24,27$, 37]. Tumors with microsatellite instability usually have a normal complement of chromosomes, i.e., a diploid or near-diploid karyotype [27]. In most other neoplasms, including brain tumors, genetic instability is typically observed at the chromosomal level and may involve gain and loss of whole chromosomes, leading to aneuploidy [27, 35]. The molecular basis of chromosomal instability is not yet fully understood, but one possible mechanism is disruption of the mitotic checkpoint $[27,35]$, i.e., a conserved function that delays anaphase in the presence of spindle damage [40], so as to increase the probability of successful delivery of an euploid genome to each daughter cell.

Three mitotic-arrest-deficient (MAD) genes, Madl, $M a d 2$, and Mad3 [14, 15, 28], three budding-uninhibitedby-benzimidazole $(B U B)$ genes, $B u b 1, B u b 2$, and $B u b 3$, $[15,39]$ and MPSI $[15,28,48]$ have been identified as being required for the execution of the mitotic checkpoint in the yeast Saccharomyces cerevisiae. Several human homologues have been identified, including hMPS1 (TTK/ MPS1L1 located on chromosome 6q13-21) [6], hMADIL1 (on chromosome 7pter-7p15) [6, 19], hMAD2 (hMAD2L1, on chromosome 4q27) [29], hMAD2B (hMAD2L2, on chromosome 1p36) [6], hBUB1 (on chromosome 2q14) [5, 6], hBUBRI ( $h B U B 1 B / M A D 3-L$ on chromosome 15q14) $[5,8]$ and $h B U B 3$ (on chromosome 10q24-26) [6, 25].

Mutational inactivation of mitotic spindle checkpoint genes appears to be involved in the evolution of some human neoplasms, in particular those with aneuploidy. 
Cahill et al. [5] detected $h B U B 1$ and $h B U B R 1$ mutations in 2 each of 19 colon cancer cell lines with chromosomal instability. Mutations in the $h B U B 1$ gene were shown to act in a dominant-negative manner, if the exogenous expression of the mutant allele disrupts the mitotic checkpoint in euploid cell lines [5]. A somatic mutation in the $h B U B 1$ gene was identified in 1 of 32 sporadic digestive tract cancers [16], in 2/148 lung cancers [12, 41], and in $1 / 10$ cases of 10 adult $T$ cell leukemia/lymphomas [34] that, in addition, contained $h B U B R 1$ missense mutations and deletion in 3 cases. In contrast, no $h B U B 1$ mutation was found in head and neck squamous cell carcinomas and lung cancer cell lines [49]. $h B U B 1$ and $h B U B R 1 \mathrm{mu}-$ tations were also reported absent in 19 aneuploid breast cancer cell lines [31]. $h B U B R 1$ mutations were not found in 47 lung cancers [41]. In addition, no $h B U B 3$ mutation was detected in 19 colon cancer cell lines [5], suggesting that mutational inactivation of these checkpoint genes is a rare event in carcinomas and malignant lymphomas.

Glioblastomas are highly aneuploid tumors and frequently show loss of heterozygosity $(\mathrm{LOH})$ on several chromosomes [3, 7, 11, 30, 38, 46, 47] in up to $90 \%$ of cases. $\mathrm{LOH}$ has frequently been observed on chromosome $10 \mathrm{q}$, where $h B U B 3$ is located. The objective of the present study was to assess whether mutational inactivation of the $h B U B 1, h B U B R 1$ and $h B U B 3$ genes is involved in the evolution of the glioblastoma phenotype.

\section{Material and methods}

Tumor samples

Twenty-two glioblastomas (WHO grade IV) were obtained from patients at the Department of Neurosurgery, University Hospital Zurich, Switzerland. Two glioblastomas (cases 72 and 295) were secondary glioblastomas that had progressed from low-grade astrocytoma. Other glioblastomas were primary (de novo) glioblastomas with a clinical history of less than 3 months. The age and sex of the patients are shown in Table 4. Twelve patients were males and ten were females. The mean age of patients at diagnosis was $55 \pm 12$ years (range $28-71$ years).

Tumor samples were immediately frozen in liquid nitrogen and stored at $-80^{\circ} \mathrm{C}$. RNA and DNA were simultaneously extracted from the same portions (about $200 \mathrm{mg}$ ) of tumors using the TRIZOL (Gibco BRL, Cergy Pontoise, France) according to the manufacturer's instructions.

The sources of 18 formalin-fixed, paraffin-embedded specimens of giant cell glioblastomas were reported previously [36]. Tumor samples included only typical cases showing a predominance of multinucleated monstrous, glial fibrillary acidic protein (GFAP)-positive tumor cells in at least one large area of the biopsy specimens. The occurrence of occasional giant cells in a glioblastoma was not considered diagnostic for this variant. Eleven patients were males and 7 were females. The mean age of patients was $42 \pm 20$ years (range $9-78$ years).

\section{hBUB1 mutations}

Screening for $h B U B l$ mutations was performed by polymerase chain reaction-single-strand confirmational polymorphism (PCRSSCP) analysis using genomic DNA. PCR amplification of the 25 exons was performed using the primers described in Table 1. Briefly, PCR was performed in a total volume of $10 \mu$ l, containing $1 \mu$ DNA solution, 0.75 U Taq DNA polymerase (Sigma, St.
Louis, Mo.), $0.5 \mu \mathrm{Ci}\left[\alpha_{-}{ }^{33} \mathrm{P}\right] \mathrm{dCTP}$ (ICN Biomedicals, N.V.S.A., Belgium; specific activity, 3,000 Ci/mmol), 1.5-2.5 mM $\mathrm{MgCl}_{2}$, $0.2 \mathrm{mM}$ of each dNTP, $0.2 \mu \mathrm{M}$ of both sense and antisense primers, $10 \mathrm{mM}$ TRIS- $\mathrm{HCl}, \mathrm{pH} 8.3$, and $50 \mathrm{mM} \mathrm{KCl}$. PCR amplification was performed in a Genius DNA Thermal Cycler (Techne, Cambridge, UK) as follows: initial denaturation for $2 \mathrm{~min}$ at $95^{\circ} \mathrm{C}$, $35-40$ cycles with denaturation at $95^{\circ} \mathrm{C}$ for $1 \mathrm{~min}$, annealing at $50-58^{\circ} \mathrm{C}$ for $1 \mathrm{~min}$ and extension at $72^{\circ} \mathrm{C}$ for $1 \mathrm{~min}$, followed by a final extension step for $5 \mathrm{~min}$ at $72^{\circ} \mathrm{C}$. After PCR, $5 \mu \mathrm{l}$ of the products was mixed with $12.5 \mu \mathrm{l}$ of loading buffer $(95 \%$ formamide, $20 \mathrm{mM}$ EDTA, $0.05 \%$ xylene cyanol and bromophenol blue), denatured at $95^{\circ} \mathrm{C}$ for $10 \mathrm{~min}$, and quenched on ice. Of the above mixture $4 \mu \mathrm{l}$ was run on a $6 \%$ polyacrylamide non-denaturing gel containing $6 \%$ glycerol at $6 \mathrm{~W}$ for $14 \mathrm{~h}$. Gels were dried at $80^{\circ} \mathrm{C}$ and autoradiographed for $12-48 \mathrm{~h}$.

Samples which showed mobility shifts in the SSCP analysis were further analyzed by direct DNA sequencing. PCR products were purified on MicroSpinTM S-300 HR Columns (Pharmacia Biotech, Uppsala) and sequenced using the Thermo Sequenase Radiolabeled Terminator Cycle Sequencing Kit (USB, Cleveland, USA) according to the manufacturer's instructions.

\section{hBUBRI mutations}

First-strand cDNA of the $h B U B R l$ gene was synthesized as follows: $5 \mu \mathrm{g}$ of total RNA in a total volume of $10 \mu \mathrm{l}$ was heated to $70^{\circ} \mathrm{C}$ for $10 \mathrm{~min}$ and then incubated at $42^{\circ} \mathrm{C}$ for $50 \mathrm{~min}$ following addition of $10 \mu \mathrm{l}$ of a mixture containing $1 \mathrm{x} 1 \mathrm{st}$ strand cDNA buffer (Gibco BRL), $10 \mathrm{mM}$ DTT, $1 \mathrm{mM}$ dNTPs, $25 \mu \mathrm{g}$ oligo-dT primers and $200 \mathrm{U}$ moloney murine leukemia virus reverse transcriptase (M-MuLV RT, Gibco BRL). cDNA samples were then made up to $40 \mu \mathrm{l}$ with distilled water and kept at $-20^{\circ} \mathrm{C}$.

Pre-screening for $h B U B R l$ mutations was carried out by PCRSSCP analysis. The entire coding region of the 3,583-bp $h B U B R 1$ cDNA was amplified as 14 overlapping fragments. PCR was performed in a total volume of $10 \mu \mathrm{l}$, containing $0.5 \mu \mathrm{l}$ cDNA solution, $0.75 \mathrm{U}$ Taq DNA polymerase (Sigma), $0.5 \mu \mathrm{Ci}\left[\alpha-{ }^{33} \mathrm{P}\right] \mathrm{dCTP}$ (ICN Biomedicals, specific activity, 3,000 Ci/mmol), $1.5 \mathrm{mM}$ $\mathrm{MgCl}_{2}, 0.2 \mathrm{mM}$ of each dNTP, $0.2 \mu \mathrm{M}$ of sense and antisense primers, $10 \mathrm{mM}$ TRIS-HCl, $\mathrm{pH} 8.3$, and $50 \mathrm{mM} \mathrm{KCl}$, in a Thermo Cycler (Stratagene, La Jolla, Calif.) as follows: initial denaturation for $2 \mathrm{~min}$ at $95^{\circ} \mathrm{C}, 35-40$ cycles of denaturation at $95^{\circ} \mathrm{C}$ for $1 \mathrm{~min}$, annealing at $50-58^{\circ} \mathrm{C}$ for $1 \mathrm{~min}$ followed by extension at $72^{\circ} \mathrm{C}$ for $1 \mathrm{~min}$, and a final extension step for $5 \mathrm{~min}$ at $72^{\circ} \mathrm{C}$. Primer sequences are shown in Table 2. After PCR, $5 \mu \mathrm{l}$ of products were mixed with $12.5 \mu \mathrm{l}$ loading buffer ( $95 \%$ formamide, $20 \mathrm{mM}$ EDTA, $0.05 \%$ xylene cyanol and bromophenol blue), denatured at $95^{\circ} \mathrm{C}$ for $10 \mathrm{~min}$, and quenched on ice. Samples of the above mixture $(4 \mu \mathrm{l})$ were run on a $6 \%$ polyacrylamide non-denaturing gel containing $6 \%$ glycerol at $6 \mathrm{~W}$ for $14 \mathrm{~h}$. Gels were dried at $80^{\circ} \mathrm{C}$ and autoradiographed for 12-48 h. Samples that showed mobility shifts in the SSCP analysis were further analyzed by direct DNA sequencing as described above.

A polymorphism at codon 349 (CAA/CGA, Gln/Arg) was detected in this study. To assess whether particular alleles are overrepresented in glioblastomas, we also analyzed blood DNA obtained from 67 healthy caucasians individuals for this polymorphism.

\section{$h B U B 3$ mutations}

First-strand cDNA of the $h B U B 3$ gene was synthesized as described above.

Pre-screening for $h B U B 3$ mutations was carried out by PCRSSCP analysis. The entire coding region of the 1,078-bp $h B U B 3$ cDNA was amplified as 5 overlapping fragments. Primer sequences are shown in Table 3. Briefly, PCR was performed in a total volume of $10 \mu \mathrm{l}$, containing $0.5 \mu \mathrm{l}$ cDNA solution, $0.75 \mathrm{U}$ Taq DNA polymerase (Sigma), $0.5 \mu \mathrm{Ci}\left[\alpha_{-}{ }^{33} \mathrm{P}\right] \mathrm{dCTP}$ (ICN Biomedicals, specific activity, $3,000 \mathrm{Ci} / \mathrm{mmol}$ ), $1.5 \mathrm{mM} \mathrm{MgCl}, 0.2 \mathrm{mM}$ of each dNTP, $0.2 \mu \mathrm{M}$ of sense and antisense primers, $10 \mathrm{mM}$ TRIS$\mathrm{HCl}, \mathrm{pH} 8.3$, and $50 \mathrm{mM} \mathrm{KCl}$, in a Thermo Cycler (Stratagene, La 
Table 1 Primers used for SSCP analyses of the $h B U B 1$ gene

\begin{tabular}{|c|c|c|c|c|}
\hline Exon & & Primer sequence & $\begin{array}{l}\text { Annealing } \\
\text { temperature }\left({ }^{\circ} \mathrm{C}\right)\end{array}$ & $\begin{array}{l}\text { Product } \\
\text { (bp) }\end{array}$ \\
\hline 1 & $\begin{array}{l}\text { Sense } \\
\text { Antisense }\end{array}$ & $\begin{array}{l}\text { TTCTAGTTTGCGGTT } \\
\text { TGAAGGACATTTTCC }\end{array}$ & 48 & 75 \\
\hline 2 & $\begin{array}{l}\text { Sense } \\
\text { Antisense }\end{array}$ & $\begin{array}{l}\text { GAAGTATATCTTTTGCTTGTAGAA } \\
\text { GGGGCAGTGTATAGTTTGTT }\end{array}$ & 52 & 175 \\
\hline 3 & $\begin{array}{l}\text { Sense } \\
\text { Antisense }\end{array}$ & $\begin{array}{l}\text { TAAACAAACTATACACTGCC } \\
\text { AAAGCAAAAGTACAACATGA }\end{array}$ & 48 & 248 \\
\hline 4 & $\begin{array}{l}\text { Sense } \\
\text { Antisense }\end{array}$ & $\begin{array}{l}\text { TTTTTGTTTTGTTCGTGT } \\
\text { ATCACAGAGAGTTTGACTTTGTAAC }\end{array}$ & 56 & 247 \\
\hline 5 & $\begin{array}{l}\text { Sense } \\
\text { Antisense }\end{array}$ & $\begin{array}{l}\text { ATTGATGCCTTTTCTGCTGT } \\
\text { GCATTTTAGAAAGCCTGATT }\end{array}$ & 52 & 94 \\
\hline 6 & $\begin{array}{l}\text { Sense } \\
\text { Antisense }\end{array}$ & $\begin{array}{l}\text { ATTATGTGATAATTTTACTTAC } \\
\text { AAAGTGGATGTAGAAGGCAG }\end{array}$ & 53 & 250 \\
\hline 7 & $\begin{array}{l}\text { Sense } \\
\text { Antisense }\end{array}$ & $\begin{array}{l}\text { TGTTTTGTGAAGTAATTTGG } \\
\text { TAAGAGCACTTAAAGGAAAC }\end{array}$ & 54 & 179 \\
\hline 8 & $\begin{array}{l}\text { Sense } \\
\text { Antisense }\end{array}$ & $\begin{array}{l}\text { TGCTCTTAGGTACATTGTTG } \\
\text { AAGAATAACTAAAAATACAAGATT }\end{array}$ & 48 & 264 \\
\hline 9 & $\begin{array}{l}\text { Sense } \\
\text { Antisense }\end{array}$ & $\begin{array}{l}\text { ATGCAAACCATTTCTATCTTTC } \\
\text { CATGAGGAGCACAACATACC }\end{array}$ & 60 & 199 \\
\hline 10 & $\begin{array}{l}\text { Sense } \\
\text { Antisense }\end{array}$ & $\begin{array}{l}\text { GATGTAATGCCTGATTAGTAG } \\
\text { CACATCACTGTGATCTCTAG }\end{array}$ & 54 & 370 \\
\hline 11 & $\begin{array}{l}\text { Sense } \\
\text { Antisense }\end{array}$ & $\begin{array}{l}\text { AGATCAAGCATTTATTCTCTAG } \\
\text { AAAATACACCTCTGAGTGATAC }\end{array}$ & 54 & 177 \\
\hline 12 & $\begin{array}{l}\text { Sense } \\
\text { Antisense }\end{array}$ & $\begin{array}{l}\text { TTCTGATTTCCCTACTGATACCAC } \\
\text { CATTAACTTGTCATCAGTGCTAC }\end{array}$ & 62 & 223 \\
\hline 13 & $\begin{array}{l}\text { Sense } \\
\text { Antisense }\end{array}$ & $\begin{array}{l}\text { TGATGACAAGTTAATGAAAGCTCT } \\
\text { TTTCTGTGATAACCACCTATAATG }\end{array}$ & 56 & 231 \\
\hline 14 & $\begin{array}{l}\text { Sense } \\
\text { Antisense }\end{array}$ & $\begin{array}{l}\text { TGATATTAGTTCTTTTCTGTCAGCT } \\
\text { CGGCAGCATCCCATTAAC }\end{array}$ & 58 & 254 \\
\hline 15 & $\begin{array}{l}\text { Sense } \\
\text { Antisense }\end{array}$ & $\begin{array}{l}\text { CAAGTGATAGCATTTATTTCCT } \\
\text { GTAGGACCCATTTCATAGATAA }\end{array}$ & 58 & 183 \\
\hline 16 & $\begin{array}{l}\text { Sense } \\
\text { Antisense }\end{array}$ & $\begin{array}{l}\text { CTTCTTTAATCCTCATTTCTTTGG } \\
\text { GAATCAAAGTTGGCAGAAGAC }\end{array}$ & 61 & 331 \\
\hline 17 & $\begin{array}{l}\text { Sense } \\
\text { Antisense }\end{array}$ & $\begin{array}{l}\text { ATCTTGTCTCTAATTTTTGAATCT } \\
\text { ACCAAATAAACCCTCACAAT }\end{array}$ & 52 & 139 \\
\hline 18 & $\begin{array}{l}\text { Sense } \\
\text { Antisense }\end{array}$ & $\begin{array}{l}\text { GGTTTCTTTATTCCTTTCACAC } \\
\text { AAGGGCATAACAAAGAGTGAG }\end{array}$ & 62 & 297 \\
\hline 19 & $\begin{array}{l}\text { Sense } \\
\text { Antisense }\end{array}$ & $\begin{array}{l}\text { TTTTTTTTTTCTCATTCСТTT } \\
\text { CGTTACCATCAАCTTCTCATAG }\end{array}$ & 48 & 232 \\
\hline 20 & $\begin{array}{l}\text { Sense } \\
\text { Antisense }\end{array}$ & $\begin{array}{l}\text { TAAAATAAAAGGCGTACATAAA } \\
\text { TCATACAAAATACAACTCAGGT }\end{array}$ & 48 & 192 \\
\hline 21 & $\begin{array}{l}\text { Sense } \\
\text { Antisense }\end{array}$ & $\begin{array}{l}\text { ATCATTTTTCAGAATACGAG } \\
\text { ATTCATGTGCTCATCATAA }\end{array}$ & 55 & 248 \\
\hline 22 & $\begin{array}{l}\text { Sense } \\
\text { Antisense }\end{array}$ & $\begin{array}{l}\text { AACTCAGGATTCCACTTT } \\
\text { AACCCTGTTAAAAGCATA }\end{array}$ & 56 & 215 \\
\hline 23 & $\begin{array}{l}\text { Sense } \\
\text { Antisense }\end{array}$ & $\begin{array}{l}\text { ATAGCAGCCTTTCATCATTTGT } \\
\text { TATTTCCAAGTCCCTCACTTTA }\end{array}$ & 60 & 261 \\
\hline 24 & $\begin{array}{l}\text { Sense } \\
\text { Antisense }\end{array}$ & $\begin{array}{l}\text { CATCTTGATATAGTCATGTGTA } \\
\text { TTAGTTATTCTCTTTTCACTAC }\end{array}$ & 44 & 226 \\
\hline 25 & $\begin{array}{l}\text { Sense } \\
\text { Antisense }\end{array}$ & $\begin{array}{l}\text { ATCCTGCATATTGAAGGCTAC } \\
\text { CAGTGTGATTTTTAAGGACTG }\end{array}$ & 56 & 289 \\
\hline
\end{tabular}

Jolla, Calif.) as follows: initial denaturation for 2 min at $95^{\circ} \mathrm{C}$, $35-40$ cycles with denaturation at $95^{\circ} \mathrm{C}$ for $1 \mathrm{~min}$, annealing at $58^{\circ} \mathrm{C}$ for $1 \mathrm{~min}$ and extension at $72^{\circ} \mathrm{C}$ for $1 \mathrm{~min}$, followed by a final extension for $5 \mathrm{~min}$ at $72^{\circ} \mathrm{C}$. Samples which showed mobility shifts in the SSCP analysis were further analyzed by direct DNA sequencing as described above.

A polymorphism at position -6 was detected in glioblastomas in this study. To assess the allelic frequency, we checked for the 
Table 2 Primers used for SSCP of the $h B U B R l$ gene

\begin{tabular}{|c|c|c|c|c|}
\hline Fragment & & Primer sequence & $\begin{array}{l}\text { Annealing } \\
\text { temperature }\left({ }^{\circ} \mathrm{C}\right)\end{array}$ & $\begin{array}{l}\text { Product } \\
\text { (bp) }\end{array}$ \\
\hline 1 & $\begin{array}{l}\text { Sense } \\
\text { Antisense }\end{array}$ & $\begin{array}{l}\text { CGGAAGAAAGCCCAGGCGGT } \\
\text { AGGGTCATTTCCAGTGTAA }\end{array}$ & 58 & 298 \\
\hline 2 & $\begin{array}{l}\text { Sense } \\
\text { Antisense }\end{array}$ & $\begin{array}{l}\text { CAAGAATCTGCCTGTAACA } \\
\text { AAAGGCTCATTGCATAAAC }\end{array}$ & 54 & 269 \\
\hline 3 & $\begin{array}{l}\text { Sense } \\
\text { Antisense }\end{array}$ & $\begin{array}{l}\text { AGAAAAACGATATTATAGTGA } \\
\text { TCСТCСТCTTCTTCTTTCTC }\end{array}$ & 50 & 312 \\
\hline 4 & $\begin{array}{l}\text { Sense } \\
\text { Antisense }\end{array}$ & $\begin{array}{l}\text { CAGCACCGACAATTCCAAGC } \\
\text { TAGAAGCCTCATCAGCATTT }\end{array}$ & 56 & 277 \\
\hline 5 & $\begin{array}{l}\text { Sense } \\
\text { Antisense }\end{array}$ & $\begin{array}{l}\text { CCTCAACAGATGCAAAATAA } \\
\text { TGGTGTCATAACTGGCTGT }\end{array}$ & 58 & 279 \\
\hline 6 & $\begin{array}{l}\text { Sense } \\
\text { Antisense }\end{array}$ & $\begin{array}{l}\text { CTCGTGGCAATACAGCTTC } \\
\text { CTTTGCTCTTTTAATTTCT }\end{array}$ & 50 & 316 \\
\hline 7 & $\begin{array}{l}\text { Sense } \\
\text { Antisense }\end{array}$ & $\begin{array}{l}\text { TTTATGCAGGAGTAGGGGA } \\
\text { AGTCATTCCTGGTATTTTC }\end{array}$ & 50 & 272 \\
\hline 8 & $\begin{array}{l}\text { Sense } \\
\text { Antisense }\end{array}$ & $\begin{array}{l}\text { TACAAAGGAGACAACTAAA } \\
\text { ATTCATCACAAACATCTGG }\end{array}$ & 53 & 323 \\
\hline 9 & $\begin{array}{l}\text { Sense } \\
\text { Antisense }\end{array}$ & $\begin{array}{l}\text { TCAAAACCTCAGAAAGCAT } \\
\text { AATAATTGGGCTCAGCTTC }\end{array}$ & 53 & 338 \\
\hline 10 & $\begin{array}{l}\text { Sense } \\
\text { Antisense }\end{array}$ & $\begin{array}{l}\text { CAGCTTGTGGCACTATCTA } \\
\text { TCCTTCTCAATTTCCAACT }\end{array}$ & 52 & 313 \\
\hline 11 & $\begin{array}{l}\text { Sense } \\
\text { Antisense }\end{array}$ & $\begin{array}{l}\text { TATAGAAGACAGACCAATG } \\
\text { GAAGATCCTGAAGGGTGAA }\end{array}$ & 51 & 311 \\
\hline 12 & $\begin{array}{l}\text { Sense } \\
\text { Antisense }\end{array}$ & $\begin{array}{l}\text { TGGCTGTATTGTTTGGCAC } \\
\text { CGCTGAGGGTAAAAACATC }\end{array}$ & 58 & 296 \\
\hline 13 & $\begin{array}{l}\text { Sense } \\
\text { Antisense }\end{array}$ & $\begin{array}{l}\text { TTCCTACAGTGTTGACCTT } \\
\text { AGCTCCCCAAGAACAGACA }\end{array}$ & 56 & 309 \\
\hline 14 & $\begin{array}{l}\text { Sense } \\
\text { Antisense }\end{array}$ & $\begin{array}{l}\text { CTGAATGCCAATGATGAGG } \\
\text { TAAATTACAGCACATACAG }\end{array}$ & 54 & 236 \\
\hline
\end{tabular}

Table 3 Primers used for SSCP analyses of the $h B U B 3$ gene

${ }^{\mathrm{a}} \mathrm{A}$ denotes pair of primers for part of genomic 5 'region

\begin{tabular}{llllc}
\hline Fragment & & Primer sequence & $\begin{array}{l}\text { Annealing } \\
\text { temperature }\left({ }^{\circ} \mathrm{C}\right)\end{array}$ & $\begin{array}{c}\text { Product } \\
(\mathrm{bp})\end{array}$ \\
\hline $\mathrm{A}^{\mathrm{a}}$ & $\begin{array}{l}\text { Sense } \\
\text { Antisense }\end{array}$ & $\begin{array}{l}\text { GCGAGTGGCGAGTAGTGGAA } \\
\text { CCCGTCCCGCACACC }\end{array}$ & 58 & 78 \\
1 & $\begin{array}{l}\text { Sense } \\
\text { Antisense }\end{array}$ & $\begin{array}{l}\text { CGTTGCTTCTGAGGGGAG } \\
\text { ATCTAGTCCTCCACTCCAGGC }\end{array}$ & 58 & 252 \\
2 & $\begin{array}{l}\text { Sense } \\
\text { Antisense }\end{array}$ & $\begin{array}{l}\text { GCCTTCTACGATCCAACGC } \\
\text { GGTCTCCAGACACTGAGAGGG }\end{array}$ & 58 & 259 \\
3 & $\begin{array}{l}\text { Sense } \\
\text { Antisense }\end{array}$ & $\begin{array}{l}\text { TCCTTGTAATGCTGGGACCT } \\
\text { TTCTTACCTCAGGGCTTGG }\end{array}$ & 58 & 267 \\
4 & $\begin{array}{l}\text { Sense } \\
\text { Antisense }\end{array}$ & $\begin{array}{l}\text { CCGAGTGGCAGTTGAGTATTT } \\
\text { CGTAGTCCCATCATTACTGAAGG }\end{array}$ & 58 & 268 \\
5 & $\begin{array}{l}\text { Sense } \\
\text { Antisense }\end{array}$ & $\begin{array}{l}\text { GGTACCCCACGAGCATCG } \\
\text { ATCCACCATTGGGGAGTACG }\end{array}$ & 58 & 234 \\
\hline
\end{tabular}

presence of this variant at genomic level in blood DNA obtained from 60 healthy caucasians individuals.

\section{Results}

hBUB1 mutations

The PCR-SSCP analysis of all 25 exons of the $h B U B 1$ gene revealed a silent mutation at codon $144(\mathrm{CAG} \rightarrow \mathrm{CAA}$,
Gln $\rightarrow$ Gln) in one of 22 glioblastomas (case 300, Table 4 and Fig. 1) and in 2 out of 18 giant cell glioblastomas. In all cases, the wild-type base $\mathrm{G}$ was also present.

hBUBR1 mutations

SSCP followed by DNA sequencing of the entire coding sequence of $h B U B R l$ revealed a silent mutation $(\mathrm{GAC} \rightarrow \mathrm{GAT}, \mathrm{Asp} \rightarrow \mathrm{Asp})$ at codon 952 in one glioblas- 
Table 4 Genetic alterations in mitotic checkpoint genes in glioblastomas

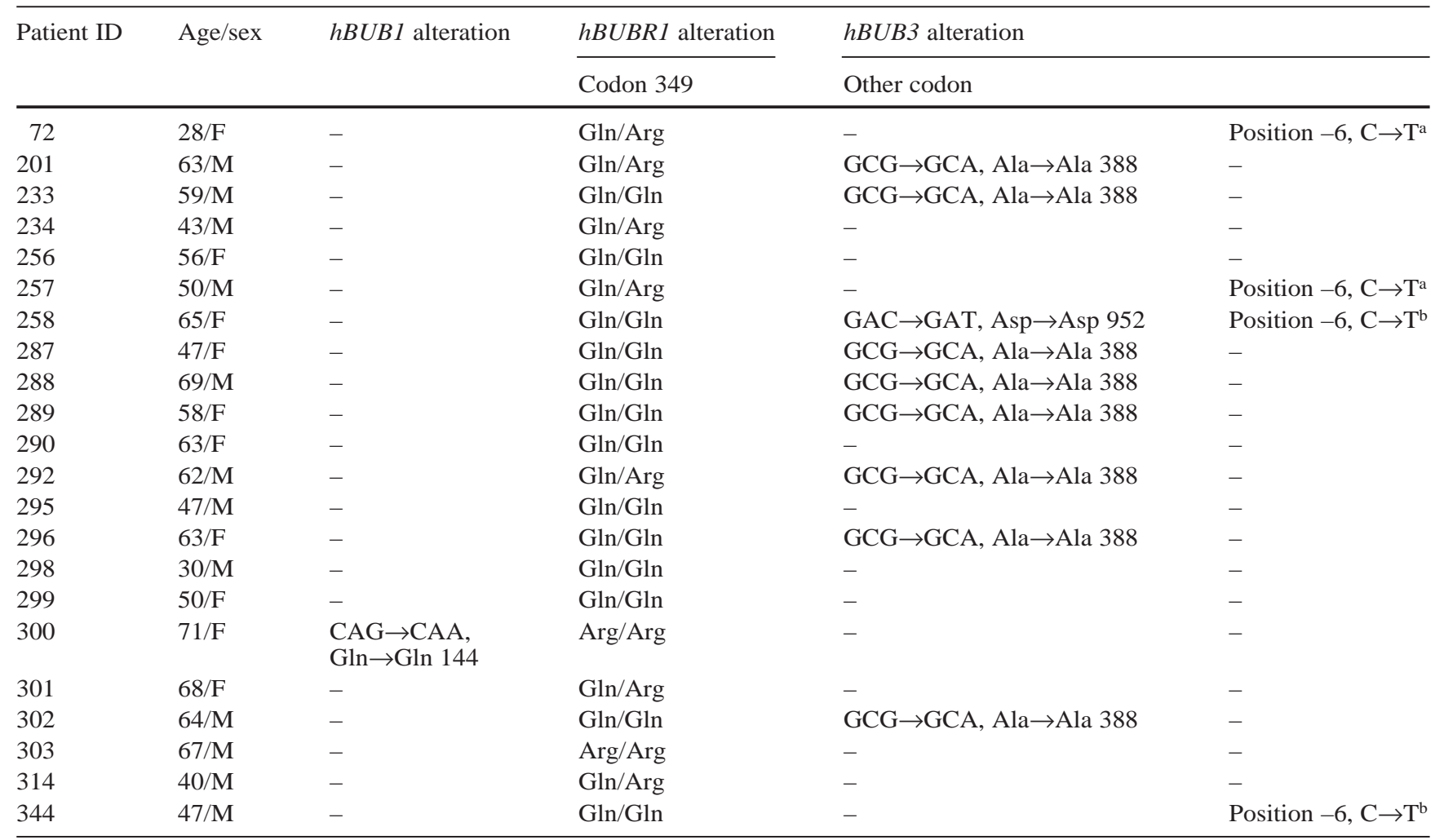

${ }^{a}$ Homozygous mutation

${ }^{b}$ Heterozygous mutation

300

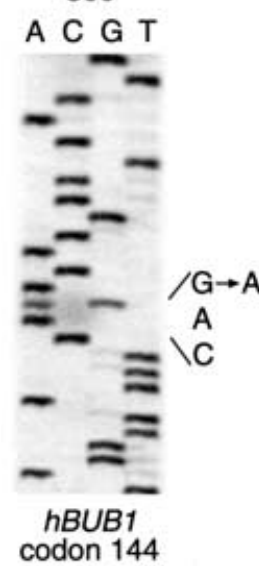

258

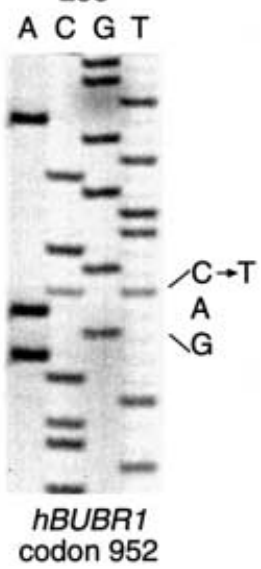

344
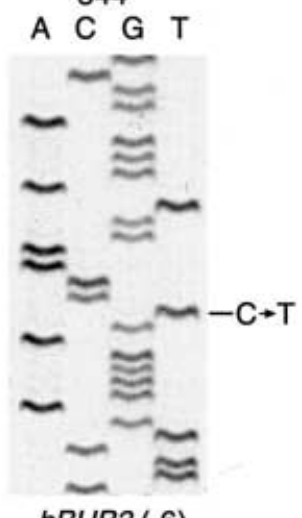

hBUB3 (-6)

Fig. 1 Representative DNA sequencing autoradiographs of silent mutations in the $h B U B 1$ gene (codon 144, CAG $\rightarrow$ CAA, Gln $\rightarrow$ Gln) and the $h B U B R 1$ gene (codon 952, GAC $\rightarrow$ GAT, Asp $\rightarrow$ Asp), and $\mathrm{C} \rightarrow \mathrm{T}$ change at -6 upstream of the initiator codon of the $h B U B 3$ gene. In cases 258 and 300, wild-type alleles are present, while in case 344 , the wild-type allele is absent

toma and another silent mutation (GCG $\rightarrow$ GCA, Ala $\rightarrow$ Ala) at codon 388 in 8 glioblastomas (Fig. 1, Table 4).

We also identified a common polymorphism at codon 349 (CAA/CGA, Gln/Arg), with allelic frequencies of 0.75 for Gln and 0.25 for Arg in glioblastomas (Table 4).

These frequencies in glioblastomas were similar to those in blood DNA samples from healthy Caucasian individuals (0.73 for Gln and 0.27 for Arg).

\section{hBUB3 mutations}

A point mutation $(\mathrm{C} \rightarrow \mathrm{T})$ was detected at 6 nucleotides upstream of the ATG initiator codon (position -6) in 4 of $22(18 \%)$ glioblastomas (Table 4, Fig. 1). Of these, the wild-type base was also present together with the mutated sequence in 2 cases, whereas the other 2 showed only mutated sequences. The analysis of blood DNA from these 4 patients showed identical alterations to those detected in tumor tissues, indicating that this alteration is a polymorphism. Screening for this polymorphism in blood DNA from healthy Caucasian individuals revealed the presence of this mutation in $9 / 60$ (15\%) individuals, a similar frequency to that in the glioblastoma patients.

\section{Discussion}

Mitotic checkpoint genes play a significant role in chromosome segregation by preventing aneuploidy $[1,5,13$, $35,40]$. During mitosis, $h B U B 1, h B U B R 1$ and $h B U B 3$ proteins localize in kinetochores before chromosome alignment and form a checkpoint kinase complex with 
other proteins. The $h B u B l$ and $h B U B R l$ genes encode protein kinases, while the $\mathrm{hBUB} 3$ protein is required for kinetochore localization of hBUB1 and hBUBR1 proteins [1, 17, 42, 45]. In Drosophila, BUB1 mutations cause chromosome missegregation and fail to block apoptosis [2]. In mice, $B U B 1$ is required not only for checkpoint response to spindle damage but also for normal mitotic timing, and for initiation of apoptosis when an apoptotic signal is present [44]. A recent study showed that the BRCA2 gene, that is associated with inherited susceptibility to breast cancer and plays a role in replication and repair of DNA during $\mathrm{S}$ phase, is phosphorylated by $h B U B R 1$ and may be involved in a mitotic checkpoint [10]. Bubl mutations were found in three out of four thymic lymphomas that developed in Brca2-deficient mice, suggesting that inactivation of these genes works synergistically in development of these tumors [26]. Bub3-null mouse embryos do not survive [20]; the embryos showed accumulation of several mitotic errors in the form of micronuclei, chromatin bridging, lagging chromosomes and irregular nuclear morphology, confirming that Bub3 is essential for normal mitosis and for early embryonic development in mice [20].

In the present study, we investigated the status of the mitotic spindle checkpoint genes $h B U B 1, h B U B R 1$ and $h B U B 3$ in glioblastomas. Screening of the entire coding sequence and intron-exon boundaries of the $h B U B 1$ gene revealed a silent mutation at codon $144(\mathrm{CAG} \rightarrow \mathrm{CAA}$, Gln $\rightarrow$ Gln) in one glioblastoma and two giant cell glioblastomas. Although we were unable to analyze normal tissue samples from these patients, this alteration is likely to be a polymorphism, since it has been previously reported in several colon tumors [6]. To date, seven different $h B U B 1$ polymorphisms have been reported in human tumor cell lines $[6,12,41,49]$. It remains to be shown whether any particular polymorphism is over-represented in cancer patients.

The analysis of the $h B U B R 1$ gene in this study showed two silent mutations at codons 952 and at 388 , both of which have previously been detected in colon and lung tumors $[6,41]$, also suggesting a polymorphism. We found another polymorphism at codon 349 (CAA/CGA, Gln/ Arg), which has previously been reported in colon and breast carcinomas $[6,21]$. The allelic frequencies of this variant in healthy individuals in Japan are 0.31 for Gln and 0.69 for $\operatorname{Arg}$ [21]. We found an opposite allelic pattern in glioblastomas ( 0.75 for Gln and 0.25 for Arg). However, our analysis of DNA from healthy Caucasian individuals showed a frequency similar to that observed in glioblastomas. This indicates that the frequency of these alleles varies significantly between ethnically different populations, but they are not over-represented in glioblastoma patients.

In the present study, $\mathrm{C} \rightarrow \mathrm{T}$ mutations were detected at 6 nucleotides upstream of the ATG initiator codon of the $h B U B 3$ gene in 4 glioblastomas. The same mutation was found in blood DNA of these patients, suggesting that this is a new polymorphism. We also carried out screening for this allelic variant in 60 healthy Caucasian individuals, and found its frequency to be similar to that in glioblastomas, suggesting that the presence of this polymorphism does not influence susceptibility to development of glioblastomas.

$\mathrm{LOH}$ on chromosome 10, in particular, loss of the 10q25-qter region, is the most frequent genetic alteration in glioblastomas, suggesting the presence of putative tumor suppressor gene(s) [38]. The $h B U B 3$ gene is mapped on 10q24-q26 [6, 25, 45]. However, the absence of miscoding mutations in $h B U B 3$ in this study excludes $h B U B 3$ as a candidate tumor suppressor gene involved in the pathogenesis of glioblastomas. We correlated the data of base change at $6 \mathrm{bp}$ upstream of initiating codon in hBUB3 and LOH on chromosome 10 published previously [9], but did not find any correlation (data not shown).

Occasional multinucleated neoplastic giant cells are a common histological feature in glioblastomas [4, 23]. Giant cell glioblastomas are defined by the predominance of large bizarre, multinucleated giant cells measuring up to $500 \mu \mathrm{m}$ [33], with near-haploid or polyploid clones [4]. Our present results show that mutational inactivation of the $h B U B 1$ gene is not associated with giant cell phenotype. Due to unavailability of frozen samples for the generation of cDNA, we could not perform a mutational analysis of $h B U B R 1$ and $h B U B 3$ genes.

In conclusion, this study shows absence of miscoding mutations in $h B U B 1, h B U B R 1$ and $h B U B 3$ genes in human glioblastomas, suggesting that mutational inactivation of these genes is not significantly involved in the aneuploidy of glioblastomas. Additional studies may be necessary to clarify whether these genes are inactivated through other mechanisms. Jaffrey et al. [18] recently detected microsatellite instability within the $h B U B 1$ gene in approximately $15 \%$ of colorectal cancers, raising the possibility that down-regulation of $h B U B 1$ may occur through instability. It also remains to be elucidated whether alterations of other mitotic spindle checkpoint genes, including $h M A D 1, h M A D 2$, and MPS1, are present in glioblastomas. However, lung, colon and digestive tract human neoplasms have a very low frequency or absence of inactivating mutations of these genes $[6,16,32,43]$.

Acknowledgements This study was generously supported by a grant from the Foundation for Promotion of Cancer Research, Japan. We are grateful to Dr. Olga Sinilnikova, IARC, for providing the DNA samples from healthy Caucasian individuals. R.M.R. was supported by a grant from the Fundação para a Ciência e Tecnologia (PRAXIS XXI), Portugal.

\section{References}

1. Amon A (1999) The spindle checkpoint. Curr Opin Genet Dev 9:69-75

2. Basu J, Bousbaa H, Logarinho E, Li Z, Williams BC, Lopes C, Sunkel CE, Goldberg ML (1999) Mutations in the essential spindle checkpoint gene bubl cause chromosome missegregation and fail to block apoptosis in Drosophila. J Cell Biol 146: 13-28

3. Bello MJ, Campos JM de, Kusak ME, Vaquero J, Sarasa JL, Pestana A, Rey JA (1994) Molecular analysis of genomic abnormalities in human gliomas. Cancer Genet Cytogenet 73: $122-129$ 
4. Bigner SH, Mark J, Bigner DD (1990) Cytogenetics of human brain tumors. Cancer Genet Cytogenet 47:141-154

5. Cahill DP, Lengauer C, Yu J, Riggins GJ, Willson JK, Markowitz SD, Kinzler KW, Vogelstein B (1998) Mutations of mitotic checkpoint genes in human cancers. Nature 392:300303

6. Cahill DP, Costa LT da, Carson-Walter EB, Kinzler KW, Vogelstein B, Lengauer C (1999) Characterization of $M A D 2 B$ and other mitotic spindle checkpoint genes. Genomics 58:181-187

7. Campomenosi P, Ottaggio L, Moro F, Urbini S, Bogliolo M, Zunino A, Camoriano A, Inga A, Gentile SL, Pellegata NS, Bonassi S, Bruzzone E, Iannone R, Pisani R, Menichini P, Ranzani GN, Bonatti S, Abbondandolo A, Fronza G (1996) Study on aneuploidy and p53 mutations in astrocytomas. Cancer Genet.Cytogenet. 88:95-102

8. Chan GK, Schaar BT, Yen TJ (1998) Characterization of the kinetochore binding domain of CENP-E reveals interactions with the kinetochore proteins CENP-F and hBUBR1. J Cell Biol 143:49-63

9. Fujisawa H, Reis RM, Nakamura M, Colella S, Yonekawa Y, Kleihues P, Ohgaki H (2000) Loss of heterozygosity on chromosome 10 is more extensive in primary (de novo) than in secondary glioblastomas. Lab Invest 80:65-72

10. Futamura M, Arakawa H, Matsuda K, Katagiri T, Saji S, Miki Y, Nakamura Y (2000) Potential role of BRCA2 in a mitotic checkpoint after phosphorylation by hBUBR1. Cancer Res 60: $1531-1535$

11. Ganju V, Jenkins RB, O'Fallon JR, Scheithauer BW, Ransom DT, Katzmann JA, Kimmel DW (1994) Prognostic factors in gliomas. A multivariate analysis of clinical, pathologic, flow cytometric, cytogenetic, and molecular markers. Cancer 74: 920-927

12. Gemma A, Seike M, Seike Y, Uematsu K, Hibino S, Kurimoto F, Yoshimura A, Shibuya M, Harris CC, Kudoh S (2000) Somatic mutation of the $h B U B 1$ mitotic checkpoint gene in primary lung cancer. Genes Chromosomes Cancer 29:213-218

13. Hardwick KG (1998) The spindle checkpoint. Trends Genet $14: 1-4$

14. Hardwick KG, Murray AW (1995) Mad1p, a phosphoprotein component of the spindle assembly checkpoint in budding yeast. J Cell Biol 131:709-720

15. Hoyt MA, Totis L, Roberts BT (1991) S. cerevisiae genes required for cell cycle arrest in response to loss of microtubule function. Cell 66:507-517

16. Imai Y, Shiratori Y, Kato N, Inoue T, Omata M (1999) Mutational inactivation of mitotic checkpoint genes, hsMAD2 and $h B U B 1$, is rare in sporadic digestive tract cancers. Jpn J Cancer Res 90:837-840

17. Jablonski SA, Chan GK, Cooke CA, Earnshaw WC, Yen TJ (1998) The hBUB1 and hBUBR1 kinases sequentially assemble onto kinetochores during prophase with hBUBR1 concentrating at the kinetochore plates in mitosis. Chromosoma 107: 386-396

18. Jaffrey RG, Pritchard SC, Clark C, Murray GI, Cassidy J, Kerr KM, Nicolson MC, McLeod HL (2000) Genomic instability at the BUB1 locus in colorectal cancer, but not in non-small cell lung cancer. Cancer Res 60:4349-4352

19. Jin DY, Spencer F, Jeang KT (1998) Human T cell leukemia virus type 1 oncoprotein Tax targets the human mitotic checkpoint protein MAD1. Cell 93:81-91

20. Kalitsis P, Earle E, Fowler KJ, Choo KH (2000) Bub3 gene disruption in mice reveals essential mitotic spindle checkpoint function during early embryogenesis. Genes Dev 14:22772282

21. Katagiri T, Futamura M, Nakamura Y (1999) A Gln/Arg polymorphism at codon 349 of the $h B U B R 1$ gene. J Hum Genet 44: 131-132

22. Kinzler KW, Vogelstein B (1996) Lessons from hereditary colorectal cancer. Cell 87:159-170
23. Kleihues P, Burger PC, Collins VP, Newcomb EW, Ohgaki H, Cavenee WK (2000) Glioblastoma. In: Kleihues P, Cavenee WK (eds) Pathology and genetics of tumors of the nervous system. IARC Press, Lyon, pp 29-39

24. Kolodner RD (1995) Mismatch repair: mechanisms and relationship to cancer susceptibility. Trends Biochem Sci 20:397401

25. Kwon TK, Hawkins AL, Griffin CA, Gabrielson E (2000) Assignment of BUB3 to human chromosome band $10 \mathrm{q} 26$ by in situ hybridization. Cytogenet Cell Genet 88:202-203

26. Lee H, Trainer AH, Friedman LS, Thistlethwaite FC, Evans MJ, Ponder BA, Venkitaraman AR (1999) Mitotic checkpoint inactivation fosters transformation in cells lacking the breast cancer susceptibility gene, Brca2. Mol Cell 4:1-10

27. Lengauer C, Kinzler KW, Vogelstein B (1998) Genetic instabilities in human cancers. Nature 396:643-649

28. Li R, Murray AW (1991) Feedback control of mitosis in budding yeast. Cell 66:519-531

29. Li Y, Benezra R (1996) Identification of a human mitotic checkpoint gene: $h s M A D 2$. Science 274:246-248

30. Louis DN (1997) A molecular genetic model of astrocytoma histopathology. Brain Pathol 7:755-764

31. Myrie KA, Percy MJ, Azim JN, Neeley CK, Petty EM (2000) Mutation and expression analysis of human BUB1 and BUB1B in aneuploid breast cancer cell lines. Cancer Lett 152:193-199

32. Nomoto S, Haruki N, Takahashi T, Masuda A, Koshikawa T, Takahashi T, Fujii Y, Osada H, Takahashi T (1999) Search for in vivo somatic mutations in the mitotic checkpoint gene, $h M A D 1$, in human lung cancers. Oncogene 18:7180-7183

33. Ohgaki H, Peraud A, Nakazato Y, Watanabe K, Deimling A von (2000) Giant cell glioblastoma. In: Kleihues P, Cavenee WK (eds) Pathology and genetics of tumors of the nervous system. IARC Press, Lyon, pp 40-41

34. Ohshima K, Haraoka S, Yoshioka S, Hamasaki M, Fujiki T, Suzumiya J, Kawasaki C, Kanda M, Kikuchi M (2000) Mutation analysis of mitotic checkpoint genes (hBUB1 and hBUBR1) and microsatellite instability in adult T-cell leukemia/ lymphoma. Cancer Lett 158:141-150

35. Orr-Weaver TL, Weinberg RA (1998) A checkpoint on the road to cancer. Nature 392:223-224

36. Peraud A, Watanabe K, Schwechheimer K, Yonekawa Y, Kleihues P, Ohgaki H (1999) Genetic profile of the giant cell glioblastoma. Lab Invest 79:123-129

37. Perucho M (1996) Cancer of the microsatellite mutator phenotype. Biol Chem 377:675-684

38. Rasheed BK, McLendon RE, Friedman HS, Friedman AH, Fuchs HE, Bigner DD, Bigner SH (1995) Chromosome 10 deletion mapping in human gliomas: a common deletion region in 10q25. Oncogene 10:2243-2246

39. Roberts BT, Farr KA, Hoyt MA (1994) The Saccharomyces cerevisiae checkpoint gene $B U B 1$ encodes a novel protein kinase. Mol Cell Biol 14:8282-8291

40. Rudner AD, Murray AW (1996) The spindle assembly checkpoint. Curr Opin Cell Biol 8:773-780

41. Sato M, Sekido Y, Horio Y, Takahashi M, Saito H, Minna JD, Shimokata K, Hasegawa Y (2000) Infrequent mutation of the $h B U B l$ and $h B U B R I$ genes in human lung cancer. Jpn J Cancer Res 91:504-509

42. Seeley TW, Wang L, Zhen JY (1999) Phosphorylation of human MAD1 by the BUB1 kinase in vitro. Biochem Biophys Res Commun 257:589-595

43. Takahashi T, Haruki N, Nomoto S, Masuda A, Saji S, Osada H, Takahashi $\mathrm{T}$ (1999) Identification of frequent impairment of the mitotic checkpoint and molecular analysis of the mitotic checkpoint genes, $h s M A D 2$ and $p 55 C D C$, in human lung cancers. Oncogene 18:4295-4300

44. Taylor SS, McKeon F (1997) Kinetochore localization of murine Bub1 is required for normal mitotic timing and checkpoint response to spindle damage. Cell 89:727-735

45. Taylor SS, Ha E, McKeon F (1998) The human homologue of Bub3 is required for kinetochore localization of Bub1 and a Mad3/Bub1-related protein kinase. J Cell Biol 142:1-11 
46. Thiel G, Losanowa T, Kintzel D, Nisch G, Martin H, Vorpahl K, Witkowski R (1992) Karyotypes in 90 human gliomas. Cancer Genet Cytogenet 58:109-120

47. Van Meyel DJ, Ramsay DA, Casson AG, Keeney M, Chambers AF, Cairncross JG (1994) p53 mutation, expression, and DNA ploidy in evolving gliomas: evidence for two pathways of progression. J Natl Cancer Inst 86:1011-1017
48. Weiss E, Winey M (1996) The Saccharomyces cerevisiae spindle pole body duplication gene MPS1 is part of a mitotic checkpoint. J Cell Biol 132:111-123

49. Yamaguchi K, Okami K, Hibi K, Wehage SL, Jen J, Sidransky D (1999) Mutation analysis of hBUB1 in aneuploid HNSCC and lung cancer cell lines. Cancer Lett 139:183-187 